\title{
RAHVUSTE TEGEMINE
}

\section{Humanitaarteaduslik vaade}

\author{
MAREK TAMM
}

$\mathrm{A}$ rutelu rahvusest ja humanitaarteadustest eeldab kõige muu kõrval sissevaadet rahvuse mõistesse, selle kriitilis-ajaloolist eritlust. Kusjuures just rahvuse ja rahvusluse määratlemisel ilmneb kõige selgemalt uurija ilmavaateline asend. Me võime endamisi loota, et rahvusi on võimalik analüüsida õpetlaslikult positsioonilt, olümposlikult kõrguselt, ent tegelikult tehakse esimesed otsustavad valikud juba mõistete defineerimisel. Rahvus ei ole mõiste, mida saaks praegu juba distantsilt uurida (nagu näiteks hõimu või seisust), rahvusriik on endiselt meie igapäevane poliitiline reaalsus ja rahvuslus laialt levinud argimõtlemise viis. Rahvuse uurimine on seega tahestahtmata poliitilin e teema. Seda poliitilist mõõdet ei pea humanitaarid aga pelgama, humanitaarteaduste üks ühiskondlikke rolle on ikka olnud enesestmõistetavaks peetava küsimuse alla seadmine, kahtluse istutamine sinna, kus kõik tundub loomulik või paratamatu. Humanitaaria ülesanne on uurida kõike inimesse puutuvat, inimese tehtut ehk inimlikke fakte (lad factum 'tehtu, tegu'). Rahvused on kindlasti üks suurejoonelisemaid inimloome vilju. Kuigi rahvusi on kerge näha igaveste või loomulikena, on need siiski inimeste endi tehtud. Rahvuste loomine on osa XVIII sajandil alguse saanud Euroopa moderniseerumise protsessist, mis kulmineerus rahvusriikide rajamisega XIX ja XX sajandil. Inimkond ei ole end alati rahvusteks jaganud, tegemist ei ole „loomuliku” organiseerumisviisiga, vaid ühes kindlas aegruumis sündinud kombega, mis on kummati osutunud väga edukaks, ja seda algkodust kaugemalgi - pole liialdus pidada rahvusluse ideoloogiat üheks Euroopa kõige edukamaks eksportkaubaks viimasel paaril sajandil.

Rahvuste, rahvusluse ja rahvusriikide uurimine on pälvinud teadlaste ulatuslikku tähelepanu ja pannud praeguseks aluse mahukale erialasele raamatukogule (vt ülevaatlikult Özkırımlı 2005, 2010; Breuilly 2013; eesti keeles Lokk 2015: 25-78). Käibel on väga mitmeid, tihti omavahel lahknevaid teoreetilisi mõisteid ja määratlusi, mis püüavad rahvusi ja rahvuslust eri nurga alt mõtestada. Seega pole imestada, et nii mõnedki õpetlased on jõudnud järeldusele, et rahvuslus on praeguseks tähendusest tühjaks voolanud, kasutu mõiste, mis pigem eksitab, kui seletab. Kui ma tosin aastat tagasi tegin intervjuu kahe teeneka rahvusluse uurija, Miroslav Hrochi ja György Schöpfliniga, siis tõrjusid mõlemad seda terminit. Esimene tõdes ühemõtteliselt: „Paljud arukad õpetlased istuvad tunde ja päevi laua taga ning uurivad mitmeid olulisi teemasid, ent nad kõik on selle „rahvusluse” mõiste vangid, mida igaüks mõistab isemoodi või ei mõista üldse. See on tüüpiline näide mõistest, mis ei aita seletada tegelikkust.” Teine sekundeeris talle samas vaimus: „Ma leian samuti, et „rahvuslus” on muutunud teaduslikus uurimistöös kasutuks mõis- 
teks. Poliitilises kontekstis on sellel mõistagi endiselt suur kaal, mis tegelikult teebki selle termini teadusliku pruugi problemaatiliseks.” (Tamm 2005)

Siinses essees on mu eesmärk osundatud hoiatuste kiuste pakkuda üks võimalik vaade rahvuste tegemise köögipoolele, sooviga veidi avada nende ajaloolist iseloomu. Sealjuures pööran põhitähelepanu erinevatele kultu u rilis tele rahvusloome praktikatele, täie teadlikkusega, et need ei ripu õhus, vaid eeldavad poliitilist ja sotsiaalset seljatagust. Hollandi ajaloolane Joep Leerssen, kes on kõige põhjalikumalt uurinud Euroopa rahvusliku mõtte kultuuriajalugu, on siinses seoses asjakohaselt rõhutanud, et rahvuslus algab alati „kultuuri rahvuslikust kultiveerimisest” (ingl national cultivation of culture), et iga rahvuslus on vältimatult kultuurirahvuslus (Leerssen 2006a, 2006b: 186-203).

Selguse huvides määratlen kohe alguses käsitluse keskse mõiste - rahvus - ja tuletan meelde selle kujunemisloo. Tänapäeva Euroopa keeltes levinud rahvuse mõiste on tuletatud ladina sõnast natio (< nasci 'sündima'), mis VanaRoomas viitas enamasti välismaalastele, st inimestele, kes ei olnud sünnipärased roomlased. Keskajal hakkas natio tähendama inimrühma, keda sidus ühine piirkondlik päritolu ja ühine keel (murrak). Rahvakeeltesse ilmus see termin keskaja lõpul, poliitilise sisu omandas rahvus alates XVII sajandist, viidates enamasti inimestele, keda valitses sama valitseja ja kes olid allutatud ühistele seadustele. Mõneti teise sisu omandas rahvus (sks Nation) uusaegsel Saksamaal, kus seda seoti rohkem ühise keele ja kultuuri, vähem seaduste ja territooriumiga (vt Kemiläinen 2001).

Tänapäevases tähenduses rahvusest kõneldes võtan aluseks määratluse, mis põhineb Briti rahvusluseuurija Anthony D. Smithi töödel, mille järgi saab rahvuse all mõista sellist inimeste kooslust, mis kannab sama nime, elab ajaloolisel territooriumil, on ennast ise rahvusena defineerinud ja mille liikmed kultiveerivad jagatud müüte, mälestusi, sümboleid, väärtusi ja traditsioone (Smith 2005). Rahvuse loomise eelduseks on Smithi järgi oluline küll teatava etnilise identiteedi olemasolu, st rahvust ei saa luua tühjale kohale, ent etniliste rühmade ja moodsate rahvuste vahel ei saa siiski tuvastada kausaalset suhet.

Rahvusest rääkides on oluline pidada silmas selle protsessuaalset loomust; rahvuslus avaneb pigem tegemises, mitte olemises. Rahvusriik on alati n-ö rahvustav riik (ingl nationalizing state, vt Brubaker 1996, 2011), kus „ei nähta vaeva mitte üksnes sellega, kuidas arendada välja funktsioneeriv administratiivaparaat ning tagada territoriaalne julgeolek, vaid saavutada ka teatavat sotsiaalset, poliitilist, majanduslikku ja kultuurilist ühtlustatust ühiskonnas, mis sageli on killustunud" (Lokk 2015: 8). Rahvuste tegemise protsessis on esmatähtis see, kuidas muuta rahvuse idee konkreetseks, „tegelikuks”, inimestele emotsionaalselt hoomatavaks, seda nii ajalises kui ka ruumilises perspektiivis. Rahvus peab selle osalistele mõjuma loomuliku ja pidevana, pakkuma teatud kogemusühtsust ja ühist tulevikuvaadet. Ühtlasi vajab rahvuslik identiteet pidevat ülekinnitamist ja edasi arendamist, st rahvusloome on pidev töö, isegi kui selle intensiivsus ajas erineb. Lihtsuse mõttes võib eristada rahvuste tegemise juures kahte peamist etappi: kui esimeses, aktiivses („kuumas”) rahvusloome faasis on oluline ühise minevikukäsituse, mälukultuuri, sümbolite süsteemi, kollektiivsete toimingute jms väljatöötamine, siis teises, passiivses 
(„külmas”) rahvusloome faasis on tähtsam rahvuse taastootmine igapäevastes praktikates, olgu nendeks spordisündmused, rahvuslikud tähtpäevad, poliitikute meie-vormis kõned, rahvussümboolika kasutamine, massimeedia jms. Seda viimast rahvusluse vormi on Michael Billig nimetanud tabavalt „banaalseks rahvusluseks”: „Banaalne rahvuslus toimib proosaliste, rutiinsete sõnade toel, mis võtavad rahvust enesestmõistetavana ja mis sel moel rahvustunnet võimendavad. Rohkem kui suured unustamatud fraasid aitavad väikesed sõnad pidevalt meelde tuletada kodumaad, muuta „meie" rahvuslik identiteet unustamatuks." (Billig 1995: 93)

Järgnevas pööran tähelepanu ennekõike rahvusloome aktiivsele perioodile, nendele peamistele tegevustele, mille tulemusena muudetakse rahvused „reaalseks”. Mõistagi on tegemist kompleksse protsessiga, mille igakülgne analüüs ei ole siinkohal mõeldav. Piirdun vaid kolme peamise aspekti eristamise ja nende põgusa lahtikirjutamisega, vaadates järgemööda seda, kuidas rahvusi on tehtud jutustamise, etendamise ja kujutamise käigus. Kokkuvõtte asemel peatun rahvuste tegemisel uurimise käigus, täpsemalt „rahvusteaduste” ajalool Eestis ja nende tänapäevasel rollil.

\section{Rahvuse jutustamine}

Rahvust aitavad luua ja koos hoida innustavad lood, rahvus on põhiolemuselt narratiivne kogukond, mille identiteet tugineb suurel määral „lugudele, mille järgi elatakse". Või täpsemalt - narratiivsetele mustritele, mis lubavad rahvusel käsitada ennast iseäraliku ja järjepidevana, siduda eraldiseisvad sündmused üheks tähenduslikuks tervikuks, selmet näha neid vaid juhuslike sattumuste summana. Need mustrid pole sealjuures mõistagi ajatud ega universaalsed, vaid igale rahvusele iseomased ning ajas teisenevad.

Rahvuse kõige olulisemad narratiivid on seotud selle minevikuga (vt Tamm 2017). Rahvuslik identiteet põhineb olulises osas sidusal narratiivil rahvusest kui ajaloolava püsivast peategelasest. Saksa ajaloolane Stefan Berger kirjutab selles seoses tabavalt: „Rahvuse loojad on olnud kõikjal ühel nõul: nende rahval peab olema ajalugu - mida pikem ja uhkem, seda parem. Rahvusliku ajalooteadvuse loomist on peetud sageli laiema rahvahulga seas tõelise rahvustunde tekitamise kõige olulisemaks eeltingimuseks, sest nii rahva etniseerimine kui ka sakraliseerimine võtab kuju vaid ajaloo ja pärandi taustal." (Berger 2007: 1) Ajaloolased on seega olnud rahvuste sepistamise tähtsad osalised, rahvusloome ja ajalookirjutus on ikka käinud käsikäes, rahvuslus on olnud üks peamisi tegureid, mis on tekitanud uut huvi ajaloo vastu, ja ajalugu on olnud tähtis aines, millest luua rahvuslikku identiteeti (Lawrence 2013; Berger, Conrad 2015). Miroslav Hroch (2015) tõdeb põhjendatult: „Rahvuslik ajalugu oli XIX sajandil üks kõige levinumaid argumente, et saavutada ühe rahvusrühma mobiliseerimine (ja ühiskondlik harimine) ning et õigustada ühe etnilise rühma eksisteerimist rahvusena." Rahvuslik ajalookirjutus lubas lugejatel arendada meie-tunnet ja näha ennast pika auväärse mineviku edasikandjatena. Hroch jätkab: „Rahvuslikud ajalood pakkusid personaalset kindlustunnet surelikkuse aseainena. Need lubasid üksikisikutel tunda, et nad 
jagasid oma esinevanemate elusid ja olid osa ühe rahvuse minevikust („meie oleme...”, „meie võitsime...”, „meie kannatasime...”).”

Niisiis on igal rahvusel mingi piiratud kogum narratiivseid mustreid, mis toetavad rahvuslikku identiteeti ja teatud mõttes mäletavad rahvuse enese eest. Ameerika kultuuripsühholoog James Wertsch on näidanud, kuidas vene rahvuslik identiteet toetub suuresti narratiivsele mustrile „välisvaenlaste väljatõrjumisest", mida on kasutatud väga paljude Venemaa minevikuepisoodide mõtestamiseks keskajast Teise maailmasõjani (Wertsch 2002). Eesti rahvuslik ajaloonarratiiv seevastu on lahutamatult seotud iseseisvuse ja vabadusvõitluse mõistega. Alates esimestest katsetest Eesti ajalugu liigendada, on seda ikka tehtud seoses vabaduse kaotamise ja võitmisega. Eestlaste ajalugu algab „muistse priiusega”, mis eelneb XIII sajandil alanud Saksa-Taani vallutusele, sellele järgneb „700-aastane orjaöö”, nagu väidab populaarne kujund, mille juured ulatuvad XIX sajandi keskpaika, siis aastail 1918-1940 uus iseseisvus sõltumatu vabariigina, seejärel Saksa ja Nõukogude okupatsioon, millele tegi lõpu iseseisvuse taastamine 1991. aastal. Seda ajaloo liigendamist toestab narratiivne muster, mis on üles ehitatud erinevate lahingute ja ülestõusude sidumisele üheks suureks võitluseks vabaduse eest. Olen seda mustrit nimetanud Eesti ajaloo „suureks vabadusvõitluseks”, mis kätkeb sajanditepikkust võitlust vabaduse eest ja sakslaste vastu. Selles narratiivses mustris lõppesid sajandeid kõik sakslastevastased väljaastumised küll kaotusega, ent need olid vaid ajutised, ja 1919. aasta juunis saavutati Vabadussõjas baltisaksa väeosade üle Võnnu all viimaks „suure vabadusvõitluse” üldvõit. See narratiivne muster on avatud iseloomuga, mis tähendab, et sellesse võib sobitada väga mitmeid konflikte (Tamm 2008, 2012: 48-64).

Kuid ajaloolaste rolli rahvuse jutustamisel ei tohi kindlasti ülehinnata, sest vähem tähtis pole olnud selles töös kirjanike ja publitsistide panus. Kirjandusteadlane Ann Rigney (2001) on veenvalt näidanud, et ajalookirjanikud olid tihti ajaloolastest edukamad ja veenvamad jutustama rahvuse ajaloolisest kogemusest, sest neid ei sidunud vajadus põhistada oma jutt tõenditega. Eriti puudutab see hääle andmist möödaniku tavainimestele, kelle vastu kutselised ajaloolased hakkasid huvi tundma alles XX sajandi teisel poolel. Kuid vähem oluline pole seegi, et ajaloojutustused levisid märksa laiemalt kui ajaloouurimused, samuti oli nende emotsionaalne ja esteetiline mõju märgatavalt suurem. Rigney toob põhjenduseks, et ajalookirjandus on omalaadi hübriidne žanr, mis põimib faktilist ja fiktiivset informatsiooni, kasutab nii ajalooallikaid kui ka autori fantaasiat. Lugejad lugesid ajaloojutte mineviku aseainena, eristamata enamasti tegelikku ja väljamõeldut, kusjuures tihti innustas ajalookirjanduse paratamatu subjektiivsus või lünklikkus lugejaid uutele tõlgendustele või teisi kirjanikke pakkuma alternatiivseid minevikupilte. Eesti on selles seoses suurepärane näide, sest rahvusliku ajalookultuuri põhilised kujundajad olid siin eeskätt kirjanikud ja ajakirjanikud, ajaloolaste roll piirdus peamiselt avalikkuses käibivate käsituste teaduslikus lihvimises, allikate ja autoriteetidega toestamises (vt Laanes, Kaljundi 2013; Kaljundi jt 2015). Eespool mainitud „suure vabadusvõitluse” narratiivne muster sündis põhilises varaste ajalookirjanike ja -publitsistide sulest ning hiljem võttis akadeemiline ajalookirjutus selle vaikimisi ja mugandustega omaks. 


\section{Rahvuse etendamine}

Rahvuslikku identiteeti ei meisterdata aga ainult tekstide toel, vaid tähtsat rolli etendavad niisamuti kõikvõimalikud kollektiivsed praktikad ehk see, mida võib nimetada rahvuse etendamiseks. Briti antropoloog Paul Connerton nendib, et rahvuslik narratiiv „on midagi enamat kui jutustatud lugu, see on etendatud kultus. Minevikupilti, isegi kui see on narratiivse mustri vormis, kantakse edasi ja kinnistatakse rituaalsetes toimingutes" (1989: 70). Rahvuse suured jutustused saavad küll enamasti alguse ajalookirjutusest ja -kirjandusest, ent sageli ületavad need peatselt kirjasõna ahtad piirid ja saavutavad täie toimeväe erinevates etenduskunstides ja avalikes rituaalides. Rahvuse vaatenurgast oluliseks peetavate tähtpäevade, sündmuste ja isikute etendamine on üks rahvusidentsuse nurgakive, üks tähtsamaid viise kollektiivselt kinnitada arusaama rahvuslikust järjepidevusest. Ühtlasi liidab rahvuslikes ühisüritustes osalemine rahvuse liikmeid, kinnistab inimeste mällu teatud väärtushinnanguid ja käitumismustreid, kinnitab indiviidi kuulumist ühisesse kogukonda, toetab selle minevikukäsituse jagamist ja edasikandmist. Koos kogetud emotsionaalsed hetked on reeglina mõjusamad kui üksi loetud tekstid.

Miroslav Hroch (2015) on pakkunud välja väikese tüpoloogia rahvuse kollektiivse etendamise peamistest viisidest, mida on tema hinnangul kokku kuus:

1) tähtpäevad, mis teadlikult või ebateadlikult põhinevad varasematel religioossetel, dünastilistel või rahvalikel pidustustel;

2) rahvusliku ajaloo tähenduslike sündmuste meenutamine;

3) rahvusliku ajaloo oluliste isikute aastapäevad ja nende monumendid;

4) rahvuskangelaste matused;

5) poliitilised kogunemised, mis väljendavad poliitilisi nõudmisi;

6) sportlikud (ja sõjaväelised) pidustused.

Käesolevas pole võimalik süveneda igasse rahvuse etendamise põhitüüpi, peatun vaid esimesel kahel, mida võib pidada võtmelisteks. Rahvusi ehitatakse enamasti varasemate etniliste või folkloorsete traditsioonide pinnasele, see aitab ülal hoida veendumust rahvuse iidsusest ja apelleerida inimeste emotsionaalsele mälule. Suur osa neist traditsioonidest liigitub ajalooliselt siiski nende hulka, mida Eric Hobsbawm on nimetanud „leiutatud traditsioonideks”. Ta kirjutab seletuseks: „,Leiutatud traditsiooni” all pean silmas toimingute kogumit, mis on tavaliselt allutatud avalikele või varjatud reeglitele, millel on sümboolne iseloom ning mille eesmärk on kordamise teel juurutada teatud väärtusi ja käitumisnorme, mis automaatselt tingivad järjepidevuse minevikuga. [---] Kuigi neis on viidatud ajaloolisele minevikule, siis „leiutatud" traditsioonide eripära on see, et järjepidevus minevikuga on neis suuresti fiktiivne." (Hobsbawm 1983: 1-2) Eestis ja Lätis pakuvad hea näite leiutatud traditsioonide etendamisest 1860. aastate lõpus alguse saanud regulaarsed laulupeod, mida rahvuslikus kultuurimälus seostatakse eestlaste või lätlaste muistse ühislaulmise kombega, ent mida tegelikult hakati korraldama saksa laulupidude eeskujul. Kui esialgu domineerisid repertuaaris pigem vaimulikud laulud ja kinnitati truudust senisele poliitilisele korrale, siis õige pea muutusid laulupeod väga oluliseks rahvusloome praktikaks, üha enam sigines 
kavva patriootlikke laule ja kõnedes viidati aina julgemalt rahvusliku iseolemise ideele. Laulupeod andsid seega tugeva tõuke rahvusliku identiteedi kujunemisele Eestis ja Lätis ning on toiminud rahvustunde toetaja ja virgutajana kõikide poliitiliste režiimide ajal tänapäevani välja.

Rahvuse etendamise selgroog on riiklik tähtpäevakalender, mis lubab regulaarselt meenutada ja tähistada neid minevikusündmusi, mida peetakse rahvuslikule identiteedile kõige olulisemateks. Kalender pakub rahvusele omalaadi performatiivse rütmi, suuremad pidustused vahelduvad väiksematega, intensiivsemad perioodid rahulikumatega. Michael Billig täheldab selles seoses: „Moodsa rahvuse aastakalender kopeerib vähendatud kujul selle pikemat poliitilist ajalugu: rahvuslike emotsioonide lühikesed ajahetked vahelduvad pikemate perioodidega, mil valitseb vaikus ja mil rahvuslus näib olevat silmapiirilt kadunud" (Billig 1995: 45). Eriline roll on rahvuse etendamisel olnud iseseisvuspäeva tähistamisel, mis on võimalus regulaarselt ja rituaalselt kinnitada rahvuslikku ühtekuuluvust (McCrone, McPherson 2009).

Rahvuslikud rituaalid on üldjuhul hoolega lavastatud, minevikusündmusi elatakse uuesti läbi ja põlistatakse aastast aastasse sama stsenaariumi järgi korduvates kõnedes või lauludes, tantsudes või paraadides. Kuid rahvuse etendamine võib mõnel juhul võtta ka vabamaid vorme, nagu on tõdenud rahvuslike argirituaalide uurija Tim Edensor: „[Rahvuslikud] etendused on sotsiaalselt ja ruumiliselt reguleeritud erineval määral. Lava võib olla hoolega valmis seatud ja osaliste tegevus koreograafiliselt rangelt fikseeritud või täpselt juhendatud. Veelgi enam, etenduste kulgu võivad kontrollida kaasosalised, et vähendada igasuguseid kõrvalekaldeid lavastuse tavapärasest koodist. Kuid samuti võivad lava piirid olla hägusad, osalised mängida erinevaid ja omavahel segamini rolle, stseenid võivad vahelduda, kavast kõrvale triivida, nendesse võivad sekkuda juhuslikud seigad, lavale võib siseneda mitme nurga alt, soodustades improviseeritud sooritusi." (Edensor 2002: 70) Rahvuse kollektiivne mäletamine tähtpäevadel on omakorda uute mälestuste lähtekohaks. Rituaalides osalejad saavad hiljem jagada oma muljeid ja kogemusi, sidudes isikliku mälu rahvuse kollektiivse mäluga. Sel moel toimub argitasandil rahvusliku identiteedi taastootmine.

Rahvuslike tähtpäevade tähistamise kõrval aitavad rahvuslikku identiteeti kinnistada ja arendada ka väiksema mastaabiga ja ebaregulaarsed ettevõtmised. Tähtis roll, eriti „banaalse rahvusluse” põlistamisel, on traditsiooniliselt olnud etenduskunstidel, eriti ajaloolistel näitemängudel, mis on aidanud valitud minevikusündmustel rahvuslikus mälus edasi kesta. Mõnel juhul võivad need näitemängud võtta populaarkultuurile iseloomulikke vorme või muutuda turistide atraktsiooniks. Eriti viimastel kümnenditel on selline rahvuslike rituaalide ja rahvusvahelise tarbimiskultuuri põimumine võtnud üha ulatuslikumaid vorme, muutunud globaalse turismitööstuse oluliseks osaks.

\section{Rahvuse kujutamine}

Tekstide ja tegevuste kõrval tuleb kolmandana esile tuua sümbolite suurt tähtsust rahvuste tegemise protsessis. Sümbolid on rahvusloomes olulised, sest need suudavad endasse koondada ja talletada rahvusele olulisi väärtusi 
ja informatsiooni. Sümbolid täidavad tihti kondenseeritud kultuurimälu rolli, mida on võimalik uutes kontekstides uuesti aktualiseerida. Juri Lotman on välja toonud, et sümbolite võimuses on määrata kultuuri rahvuslikke piire: „Domineerivate sümbolite põhikogumi ühtsus ja nende kultuuriline eluiga määravad suuresti kultuuride rahvus- ja areaalipiirid” (1999: 224). Sümbolil on Lotmani käsituses omalaadi topeltiseloom: ühest küljest teostab ta kultuurikihistusi läbides oma invariantset olemust, teisest küljest aga korreleerub aktiivselt uute kultuurikontekstidega, sealjuures ise nende mõjutamise käigus teisenedes (vt Tamm 2013). Kokkuvõttes ilmneb sümbol rahvusliku identiteedi kontekstis niisiis otsekui „semiootiline kondensaator”, mis panustab korraga nii väärtushoiakute säilitamisse kui ka nende edasiarendamisse.

Taas on Miroslav Hroch (2015) välja pakkunud kasuliku rahvussümbolite tüpoloogia, tuginedes nende kasutamise kontekstile ja vormile:

1) avalikud tegevused (paraadid, pidustused, matused, kogunemised);

2) sõnalised pöördumised (motod, deklaratsioonid, laulud, hümnid);

3) ikonograafilised sümbolid (pildid, portreed, ajaloomaalid, lipud, margid, plakatid);

4) monumendid;

5) „rahvuslik” maastik ja selle osad.

Peatun siinkohal veidi pikemalt vaid kolmandal sümbolitüübil, mis etendab keskset rolli selles rahvuse tegemise viisis, mida võib nimetada „rahvuse kujutamiseks". Kui kollektiivsed toimingud annavad rahvustundele kogetava mõõtme, siis kujutav kunst pakub rahvuslikule identiteedile visuaalse vormi, muudab rahvuse selle liikmetele otsekui silmaga nähtavaks. Visuaalkunstnike roll on tõlkida abstraktne rahvuse idee kergesti haaratavasse ja emotsionaalselt laetud kujundikeelde. Anthony Smith, kes on seni kõige huvitavamalt uurinud rahvuse loomist visuaalsete vahenditega, sedastab kokkuvõtlikult: „Visuaalkunstide, maali, skulptuuri ja arhitektuuri, ent hiljem ka filmi, televisiooni ja reklaami vahendusel saab rahva silme ette manada rahvuse, selle iseloomu, ajaloo ja saatuse, lasta sel paista elava, nähtava ja käegakatsutavana" (Smith 2013: 9).

Kui tänapäeval, „banaalse rahvusluse” perioodil, on kõige tähtsamad meediumid rahvuse kujutamisel televisioon ja film, siis ajalooliselt, rahvusloome varases faasis, oli põhiroll ajaloopiltidel. Pildid aitasid panustada rahvusliku genealoogia konstrueerimisse, rahvuslike tähtpäevade ja kangelaste kaanoni kujunemisse. Konkreetsemalt maalikunstis saab eristada kahte põhižanri, mis on mänginud kõige olulisemat rolli rahvuste tegemises: ajaloo- ja maastikumaal. XIX sajandil mitmel pool Euroopas suure populaarsuse võitnud ajaloomaal lubas esimest korda anda ajaloonarratiividele visuaalse vormi, muuta ajalookangelased otsekui luust ja lihast inimesteks, tuua tähenduslikud minevikusündmused uuesti inimeste pilgu alla, nii eeskujuks kui ka innustuseks. „Ajalooliste stseenide kujutised,” kinnitab Hroch (2015), „on saatnud rahvusliku liikumise algusest peale ajaloonarratiive ja need on olnud väga tõhusad rahvusliku agitatsiooni vahendid." Kuid mõneti ootamatult ei jäänud XIX sajandil ajaloomaalile tähtsuselt alla maastikumaal, mis kujundas arusaamasid rahvuslikest maastikest, rahvuse „loomulikust” keskkonnast. Kui ajaloomaal sidus rahvust ajalises perspektiivis, siis maastikumaal panustas rahvuse ruumilisse lõimimisse, või Anthony Smithi sõnadega, „kui maastiku- 
maalijad aitasid rahvuslikku kogukonda ja selle ajalugu „naturaliseerida”, siis ajaloomaalijad soovisid rahvust „historiseerida” ja varustada seda teatud kindla ajaloolise iseloomuga" (2013: 82).

Hea võrdleva ülevaate visuaalkultuuri tähtsusest rahvuste tegemisel pea kahekümnes Euroopa riigis pakub Monika Flacke koostatud koguteos „Rahvuste müüdid: Euroopa panoraam” (1998), mis põhineb tema 1998. aastal Berliinis kureeritud esinduslikul näitusel. Ühtlasi joonistub raamatust hästi välja, et pildid ei ole etendanud eri rahvuste tegemisel ühesugust rolli, on piirkondi, kus rahvuslik identiteet tugines ulatuslikult visuaalkultuuril, ent ka neid, kus pildid ei tõusnud kunagi tekstide ja rituaalidega samale pulgale. Eestiski on ajaloopiltidel olnud rahvusloome protsessis võrdlemisi väike roll, kuigi seda ei saa kindlasti pidada olematuks (vt Kreem 2015).

\section{Rahvuse uurimine}

Rahvuste jutustamise, etendamise ja kujutamise kõrval ning nendega põimitult on rahvusloomes mänginud olulist rolli rahvuste uurimine, see valdkond, mida oleme eesti keeles harjunud nimetama rahvuslikeks või rahvusteadusteks. Tõtt-öelda ma ei tea, millal see tõenäoliselt saksa keelest (nationale Wissenschaften $){ }^{1}$ kuid võimalik, et hoopis soome keelest (kansalliset tieteet) ${ }^{2}$ laenatud nimetus eesti keeles käibele tuli, ent vähemalt 1930. aastate alguseks oli see avalikes arutlustes võrdlemisi kodunenud. ${ }^{3}$ Tollest ajast pärinevad ka esimesed katsed uut mõistet määratleda ja põhjendada. Nii sedastas etnoloog Ferdinand Linnus rahvusteaduste eesmärgina „oma” ja „võõra” eristamise: „Rahvuslikud teadused annavad [---] vastuse küsimusele, mis meie kultuurvarades on võõrastelt laenatud ja mis oma algupära ja annavad meile seega mõõdupuu meie kultuuri üksiknähete suhtelise väärtuse hindamiseks." (Leinbock 1933: 50) Mõni aasta hiljem selgitas keeleteadlane Julius Mägiste (1937: 358), et kuigi rahvuslikeks teadusteks võib liigitada kõiki Eestisse puu-

${ }^{1}$ Saksa nationale Wissenschaften väike värdvorm oli Natsi-Saksamaal viljeletud völkische Wissenschaften'i ('rahvateaduste') kontseptsioon, mille juured ulatuvad tagasi XIX sajandisse (vt Weindling 2017; Puschner 2017).

${ }^{2}$ Sellele viitab näiteks tõsiasi, et Digaris eesti artiklite seas tehtud sõnaotsing pakub kõige vanema rahvusteaduste vastena ühe 1926. aasta 4. juulil Postimehes ilmunud arvustuse soomekeelsest entsüklopeediast „Suomi. Maa. Kansa. Waltakunta, III”, kus muuseas seisab: „Eestkätt pakuvad palju huvitavat meilegi ülevaated n.n. rahvusteaduste (soomeugri keeleteadus, etnograafia, arheoloogia jne.), millised Soomes kõrgele arenenud ja mille areng Eesti vastavate teadusharudega mitmeti seotud." Ja kui aasta hiljem teeb August Annist Eesti Kirjanduses ülevaate Soomes ilmunud uudiskirjandusest, mainib ta, et Soome akadeemilises ilmas on „rahvuslikud teadused” aktiivsemalt viljeletud kui „üldteadused” (Annist 1927: 127). Huvitav on veel selles seoses täheldada, et 1939. aasta juuni alguses korraldati Helsingis Soome-Eesti „rahvuslikkude teaduste kongress”, kust võttis osa u 80 teadlast, neist 20 Eestist (Uus Eesti 2. VI 1939, lk 1). Plaan oli aasta pärast sama kongress Tallinnas korraldada, ent mõistetavatel põhjustel ei saanud sellest asja. Ka Julius Mägiste (1973: 235) on pakkunud, et soome kansalliset tieteet olid eeskujuks eesti „rahvuslike teaduste” terminile. „Rahvusteaduste” kontseptsiooni ajaloost Soomes vt Fromm 1999.

${ }^{3}$ Samas kohtab seda siin-seal juba ka 1920. aastatel, näiteks figureerib see mitmel korral Veljesto koguteoses „Mõtteid valmivast intelligentsist” (Annist 1923: 38, 48; Moora 1923: $64)$, vt ka eelmine viide. 
tuvaid teadusvaldkondi, siis „selle nimetuse kitsamas, tavalises mõttes meil mõistetakse ainult teatavaid humanitaarteaduste alasid, mis kõige otsemalt teotsevad meie maa ja rahvuskultuuri mineviku ning oleviku uurimisega, ja need on: Eesti ajalugu ja sellele lähedane muinasteadus (arheoloogia), eesti rahvateadus (etnograafia), eesti rahvaluuleuurimine, eesti keele ja sugukeelte uurimine ja eesti kirjandusteadus". ${ }^{4}$ Juba uutes oludes, 1943. aastal, sekundeeris talle etnoloog Gustav Ränk: „Laiemas mõttes võib rahvusteaduste hulka lugeda kõik teadused, mida üks rahvas oma intellektuaalsete jõududega omal maal arendab, kuid tavaliselt piiritletakse meil rahvusteaduste hulka ainult osa humanitaarteadusi, mille uurimisalaks on rahvakultuur oma eri avaldusvormidega - keele, luuleloomingu, traditsioonide ja kultuuri aineliste mälestusmärkidega kui ka selle rahva ajalugu, kirjandus- ja kunstiajalugu." (Ränk 1943: 3)

Mõneti avarama vaatenurga pakkus 1936. aastal välja antropoloog Juhan Aul: „[---] rahvuslikeks teadusiks me nimetaksime need teadused, mille objektiks on kõik see, mis rahva juures ja tema eluruumis on ainulaadne, eriilmeline, kordumatu mujal - rahvas ise kui looduslik tervik, rahva eluavaldused kogu nende mitmekesisuses, nii ruumilises kui ka ajalises, rahva eluruum kogu selle rikkuses jne." (Aul 1936: 206) Samuti tavapärasest avaramast, maiskondlikust printsiibist lähtus keemik Jaan Kalviste, kelle hinnangul tuleb teha rahvuslikel ja rahvusvahelistel teadustel vahet territoriaalselt. Esimeste hulka kuuluvad need, kes „kasutavad oma uurimise objektiks eeskätt kodumaist ainestikku. Siia kuuluvad reaalaladel geograafia, geoloogia, zooloogia jt., humanitaaraladel ajalugu, keeleteadus, rahvaluule-teadus jt." (Kalviste 1936: 78) Teiste hulka liigitab ta aga näiteks matemaatika, füüsika, astronoomia ja keemia. Samas peab ta oluliseks täpsustada, et ei soovi sugugi „alahinnata rahvusliku teaduse tähtsust rahvusvahelise kultuuri tegurina” ja et „rahvuslik teadus, seistes rahvusvahelise teaduse tasemel, moodustab tähtsa lüli universaalses teaduses ja täidab olulist osa universaalse inimkultuuri arengus” (Kalviste 1936: 79). Oma arutluse lõpetab ta üldise järeldusega, et „rahvuslike ning kodumaiste teaduste ülesandeks on eeskätt meie rahvast ja kodumaad puutuva ainestiku käsitlemine, nendega seoses olevate probleemide uurimine ja saavutatud tulemuste kättesaadavaks tegemine ning lisandamine kogu inimkonna kultuurisaavutiste varaaita." Siin tasub tähele panna tsitaadis figureerivat mõistet „kodumaised teadused”, mis oli 1930. aastatel rahvuslike teaduste rööpnimetusena üsna laialt käibel. Samas leidus ka autoreid, kes neil kahel mõistel vahet tegid, nii näiteks arheoloog Richard Indreko: „Nagu üldiselt teada, kuuluvad rahvuslike teaduste alla keeleteadus, etnograafia, rahvaluule, ajalugu, muinasteadus, antropoloogia, genealoogia j. m. Ka kodumaiste teaduste haru on kaunis laialdane, nimetades tähtsamatena neist geoloogiat, botaanikat, maateadust, zooloogiat jne." (Indreko 1937: 11)

Rahvuslike või rahvusteaduste mõiste ajalugu vaadates torkab silma, et seda on sobinud kilbile tõsta iga poliitilise korra ajal. Nagu nägime, oli see täh-

${ }^{4}$ Artikli aluseks oli 24. veebruaril 1934 Tartu Ülikoolis peetud ettekanne „Rahvuslikkude teaduste arengust eesti ülikoolis" (vt Vaba Sõna 28. II 1934, lk 6).

${ }^{5}$ Mõned aastad varem eristas maiskondlikkuse põhimõttel ka Eesti Vabariigi haridusministeeriumi teaduse ja kunsti osakonna juhataja Gottlieb Ney (1934: 9) ülejäänud teadustest „rahvuslikud või kodumaised teadused”. 
tis teema sõjaeelses vabariigis, ent kui napi ainese pealt saab üldistada, siis tundub, et rahvusteaduste kaart ei olnud minetanud oma väärtust ka Saksa okupatsiooni ajal. Sellest annab aimu Gustav Ränga Tartu Ülikoolis 24. veebruaril 1943 peetud aulakõne „Saavutusi eesti rahvusteaduste uurimistöös iseseisvuse ajal", kus ta viitab rahvusteaduste erilisele vajalikkusele olukorras, kui idast ähvardab taas hädaoht: „Nagu eile, nii vajab rahvas täna ja hommegi tugevat mineviku traditsioonidel põhjenevat eneseteadvust, ja siin on asendamatu osa täita meie rahvusteadustel. Eriti viimased saatuslikud aastad eesti rahva ajaloos on selgesti näidanud, kus peituvad rahva enesesäilitamise eod: rahvalt võidakse röövida kõik, tema varandus, tegutsemisvõime, isegi ta au, kuid millele ükski võim juurde ei pääse, see on rahva ajalooline enesetunnetamine ja selt põhjalt võrsuv usk tulevikku." (Ränk 1943: 3)

Ränga kõne taustal on kõnekas, et Nõukogude Eesti ideoloogid hindasid ise oma panust rahvusteaduste arendamisse väga kõrgelt. Tehes Nõukogude tagalas kokkuvõtet esimesest nõukogude aastast Eestis, kirjutab ENSV hariduse rahvakomissar Nigol Andresen: „Nõukogude Eestis olid intensiivse uurimise osalisteks eesti rahvuslikud teadused - eesti ajalugu, eesti keel, eesti kirjandus, eesti etnograafia. Neile aladele koondati kõik uurimisvõimelised töötajad. Seni tööta olnud noored teadlased tõmmati tööle ja juba osutasid nad esimesi hiilgavaid tulemusi töös." (Andresen 1943: 43) Kolm aastat hiljem, kui Eesti oli uuesti Nõukogude Liiduga liidetud, tõdes Andreseni mantlipärija Jüri Nuut, kutselt matemaatik, samas vaimus: „Nõukogude Eestis omavad suurt eritähtsust eesti rahvuslikud teadused, keelelised uurimused, eesti folkloor, eesti rahva ajaloolise arenemiskäigu küsimused. Seepärast ongi arusaadav, et just selles teaduste tsüklis Nõukogude Eesti teadlased on ainulaadsed ja peavad sammuma esirindel." (Nuut 1946: 414) Tõsi, tundub, et pärast esimest entusiasmi vajus nimetus unarusse, eriti pärast 1950 . aasta EK(b)P KK märtsipleenumit (mille üheks ohvriks olid ka mõlemad osundatud rahvakomissarid), kui rahvusteadused mõneks ajaks jälle sahtlisse pandi; seda sõnaühendit kohtab nõukogude kirjasõnas võrdlemisi harva (ent vt nt Laas 1980: 7). Kui aga majandusteadlane Arno Köörna pakkus 1986. aastal lühiülevaate Eesti NSV teadusest, siis ei unustanud ta mõneti üllatavalt käsitlemast ka rahvusteadusi (peatükis „Rahvusteaduste kiire progress”), mille alla ta liigitas ajaloo, arheoloogia, keeleteaduse, kirjandusteaduse, etnograafia, folkloristika ja kõik kunstiteadused. Ajastu dialektilise retoorika hea näitena õigustas ta teemavalikut järgmiselt: „Rahvuskultuuri ja nõukogude rahvaste internatsionaalse kultuuri vahel on dialektiline seos - esimese uurimine aitab sügavamalt ja paremini mõista ka teist" (Köörna 1986: 24). ${ }^{6}$

${ }^{6}$ Olgu veel osundatud üht huvitavat rahvusteaduste tõlgendust 1983. aastast, mille pakkus ajaloolane Juhan Kahk ühes intervjuus, kus ta kommenteeris ENSV Teaduste Akadeemias toimunud arutelu rahvuskultuuri uurivate teaduste olukorrast ja ülesannetest: „Teaduse internatsionaalse põhiolemuse tõttu puudub teadussüstemaatikas mõiste „rahvusteadus(ed)”. Kuid samal ajal on teadus- ja kultuurielu praktikas kujunenud teatud teadusharude rühmitus, millel on eriline tähendus rahvuskultuuri arengu seisukohalt. Rahvuslikku kultuuri, selle ajaloolisi juuri ning peamist kandjat - keelt - uurivad ajaloo- ja filoloogiateadused võib tinglikult viia ühise nimetaja alla - rahvuskultuuri uurivad teadused. Siia kuuluvad lingvistika ja kirjandusteadus kõigi oma alajaotustega; etnograafia, folkloristika; ajalugu koos arheoloogiaga ning kõik kunstiteadused (kujutava kunsti, muusika, teatri- ja filmikunsti ajaloo ja nüüdisprotsesside uurimine). Neis valdkondades arendata- 
Nagu hästi teada, on mõiste rahvusteadused teinud uuel sajandil uue tähelennu, seda peaasjalikult seoses Haridus- ja Teadusministeeriumi määrusega 2005. aastast, mis kehtestas rahvusteaduste kategooria teadusasutuste baasfinantseerimise korras ja ministeeriumi initsiatiiviga rahastada alates 2012 . aastast Tartu Ülikooli juures kümmet nn rahvusprofessuuri (vt Rahvusvahelised rahvusteadused... 2014). Ma ei peatu siinkohal nendest algatustest sündinud elaval arutelul, sest seda on piisava põhjalikkusega eritlenud Urmas Sutrop (2012) oma artiklis „Kuidas me mõistame rahvusteadust”. Ei salga, et rahvusteaduste võidukas naasmine avalikku keelepruuki on üllatav, sest kui see termin oli omal kohal sõjaeelsel perioodil, aktiivse rahvusloome tingimustes, ja selle propagandistlikku väärtust on lihtne taibata võõrvõimu kontekstis, siis tänapäeva teaduspildis on selle kasutamine kaunis kummaline. Nii on viimasel viieteistkümnel aastal maailmas aktiivset arutelu põhjustanud küsimus „metodoloogilisest rahvuslusest” (ingl methodological nationalism), ${ }^{7}$ st sellisest metodoloogilisest lähenemisest, mis võtab rahvust (rahvusriiki) ühiskonna käsitlemise loomuliku alussüsteemina, lähtudes eeldusest, et „rahvus kujutab endast püsivat vaatlusüksust läbi kõigi ajaloo vältel toimuvate muutuste" (Wimmer, Glick Shiller 2002: 305). Metodoloogilise rahvusluse kriitikud toovad põhjendatult välja, et rahvust ja rahvusriiklust ei saa käsitada igavese või etteantuna, vaid ajas teiseneva nähtusena, mis vajab sellisena ise historiseerimist. Selle suuna heaks näiteks siinse essee kontekstis on uurimused teaduse ja rahvusluse keerulistest vahekordadest XIX ja XX sajandil (vt nt Jordanova 1998; Jessen, Vogel 2002). Rahvusteadusi tundub seega kõige adekvaatsem käsitleda kindla ajaloolise nähtusena, mis kuulub aktiivsesse, „kuuma” rahvuste tegemise perioodi, ja on tänapäeval huvitav ja tänuväärne ajaloolise uurimistöö objekt.

Praegusel, „banaalse rahvusluse” ajastul, mida uhuvad üleilmastumise lained, on küllap kohasem rääkida kas kitsas mõttes Eesti uuringutest (ingl Estonian studies), st teadusvaldkonnast, mis tegeleb Eestiga seotud ainese uurimisega (sõltumata distsiplinaarsest vaatenurgast) või siis üldiselt humanitaar- ja sotsiaalteadustest kui n-ö tagasisideteadustest, mille üks missioone on ikka olnud kultuurile enesemõistmise võime tagamine (Torop 2011: 8) ja kus uurija kultuuriline ning sotsiaalne identiteet on uurimisteemaga paratamatult põimunud.

Essee aluseks on EV100 kunstinäituse „Riik ei ole kunstiteos” (Tallinna Kunstihoone, kuraator Katerina Gregos) kataloogi jaoks kirjutatud tekst, mida on käesolevas arendatud ja täiendatud. Tööd toetas Eesti Teadusagentuuri grant IUT18-8.

vad uurimused kuuluvad orgaaniliselt üleliidulise ja ülemaailmse teaduse koosseisu ning kohalike ülesannete lahendamisel tuleb püüelda selle poole, et anda panus internatsionaalsesse teadusesse. Nimetatud teaduste peamine ülesanne on aidata kaasa rahvuskultuuri optimaalsele arengule, kindlustada arengu järjepidevus ja vastastikku viljastavad kontaktid vennasrahvaste ja internatsionaalse kultuuriga." (Kahk 1983: 2) Pean tõenäoliseks, et eespool mainitud Köörna raamatu peatükk rahvusteaduste progressist ENSV-s võlgneb nii mõndagi Kahkile.

${ }^{7}$ Eesti riigiteadlased on seda ingliskeelset terminit tõlkinud ka kui metodoloogiline rahvusriiklus (vt Kalev jt 2015). 


\section{Kirjandus}

[Andresen, Nigol] 1943. Haridus ja kultuur Nõukogude Eestis. ENSV Hariduse Rahvakomissari Nigol Andreseni raadiokõne ENSV kolmanda aastapäeva puhul. - Nõukogude Eesti 3. aastapäev (1940-1943). Moskva: ENSV Riiklik Kirjastus, lk 41-45.

Anni[st], August 1923. Meie ilmast ja meie ilmavaatest. - Mõtteid valmivast intelligentsist. Tartu: Odamees / Carl Sarap, lk 7-53.

A[nnist], A[ugust] 1927. Märkmeid hõimu ja maailmakirjanduse alalt. - Eesti Kirjandus, nr 2, lk 124-128.

A u l, J[uhan] 1936. Intensiivsemale loomingule rahvuslike teaduste alal. - ERK, nr 9-10, lk 205-211.

B e r g e r, Stefan 2007. Introduction: Towards a Global History of National Historiographies. - Writing the Nation. A Global Perspective. Toim S. Berger. Basingstoke: Palgrave Macmillan, lk 1-29.

B er ger, Stefan, C o n r a d, Christoph 2015. The Past as History: National Identity and Historical Consciousness in Modern Europe. Basingstoke: Palgrave Macmillan.

Billig, Michael 1995. Banal Nationalism. London: SAGE Publishing Ltd.

B r euilly, John (toim) 2013. The Oxford Handbook of the History of Nationalism. Oxford: Oxford University Press.

Brubaker, Rogers 1996. Nationalism Reframed: Nationhood and the National Question in the New Europe. Cambridge: Cambridge University Press.

Brubaker, Rogers 2011. Nationalizing states revisited: Projects and processes of nationalization in post-Soviet states. - Ethnic and Racial Studies, kd 34, nr 11, lk 1785-1814.

Connerton, Paul 1989. How Societies Remember? Cambridge: Cambridge University Press.

Edensor, Tim 2002. National Identity, Popular Culture and Everyday Life. Oxford-New York: Berg.

Fla cke, Monika (toim) 1998. Mythen der Nationen, Bd. 1: Ein europäisches Panorama. Berlin: Koehler \& Amelang.

Fr o m m, Hans 1999. Der Weg der „nationalen Wissenschaften” durch die finnische Geschichte über 150 Jahre. - Zur Geschichte und Problematik der Nationalphilologien in Europa: 150 Jahre Erste Germanistenversammlung in Frankfurt am Main (1846-1996). Toim Frank Fürbeth, Pierre Krügel, Ernst Erich Metzner, Olaf Müller. Tübingen: Max Niemeyer Verlag, lk 157-168.

Hobsbawm, Eric 1983. Introduction: Inventing traditions. - The Invention of Tradition. Toim E. Hobsbawm, Terence Ranger. Cambridge: Cambridge University Press, lk 1-14.

Hro ch, Miroslav 2015. European Nations: Explaining Their Formation. London: Verso.

[Indreko, Richard] 1937. Rahvuslike ja kodumaiste teaduste arendamisest. (Kokkuvõte mag. R. Indreko poolt kitsamas ringis peetud ettekandest). - Akadeemia, nr 1, lk 11-16.

Jes s e n, Ralph, Voge l, Jakob (toim) 2002. Wissenschaft und Nation in der europäischen Geschichte. Frankfurt am Main: Campus Verlag. 
J or d a n ov a, Ludmilla 1998. Science and nationhood: Cultures of imagined communities. - Imagining Nations. Toim Geoffrey Cubitt. Manchester: Manchester University Press, lk 192-211.

[Kahk, Juhan] 1983. Rahvuskultuuri uurimisest. [Intervjuu ENSV Teaduste Akadeemia Ühiskonnateaduste Osakonna akadeemik-sekretäri Juhan Kahkiga]. Sirp ja Vasar 30. III.

Kalev, Leif, Vetik, Raivo, Jak obs o n, Mari-Liis 2015. Metodoloogiline rahvusriiklus ja selle kriitika. - Acta Politica Estica, nr 6, lk 20-36.

Kaljundi, Linda, La a nes, Eneken, Pikkan en, Ilona 2015. Introduction: Historical fiction, cultural memory and nation building in Finland and Estonia. - Novels, Histories, Novel Nations: Historical Fiction and Cultural Memory in Finland and Estonia. Toim L. Kaljundi, E. Laanes, I. Pikkanen. Helsinki: Suomalaisen Kirjallisuuden Seura, lk 26-75.

Kalviste, J[aan] 1936. Rahvuslike teaduste tähtsusest ja nende ülesannetest. ERK, nr 3-5, lk 78-81.

Ke milä in en, Aira 2001. „Nation”: A survey of the term in European languages. - Encyclopedia of Nationalism. Toim Athena Leoussi. New Brunswick, NJLondon: Transaction Publishers, lk 203-208.

Kr e e m, Tiina-Mall (koost) 2015. Kunstnik ja Kleio. Ajalugu ja kunst 19. sajandil. (Eesti Kunstimuuseumi Toimetised 5 (10).) Tallinn: Eesti Kunstimuuseum.

Köörn a, Arno 1986. Teadus rahva teenistuses. Tallinn: Perioodika.

La anes, Eneken, Kaljundi, Linda 2013. Eesti ajalooromaani poeetika ja poliitika. Sissejuhatuseks. - Keel ja Kirjandus, nr 8-9, lk 561-578.

L a a s, Jaan 1980. Kultuuriloome katkematus voolus. - Sirp ja Vasar 27. VI.

Law rence, Paul 2013. Nationalism and history writing. - The Oxford Handbook of the History of Nationalism. Toim John Breuilly. Oxford: Oxford University Press, lk 713-730.

Leers s e n, Joep 2006a. Nationalism and the cultivation of culture. - Nations and Nationalism, kd 12, nr 4, lk 559-578.

Le e r s s e n, Joep 2006b. National Thought in Europe: A Cultural History. Amsterdam: Amsterdam University Press.

Lein b ock [= Linnus], F[erdinand] 1933. Eesti rahvusteaduste areng: Tuleviku ülesanded ja nende tähtsus eesti rahvuskultuuri arendamisel. - Eesti rahvuskultuur: koguteos Eesti Vabariigi 15. aasta juubeliks. Tartu: Eesti Rahvuskultuuriline Ühing, lk 50-55.

Lokk, Reigo 2015. Sepistades natsiooni: taasiseseisvunud Eesti etnopoliitilised konfliktid. (Dissertationes historiae Universitatis Tartuensis 35.) Tartu: Tartu Ülikooli Kirjastus.

L o t m a n, Juri 1999. Sümbol kultuurisüsteemis. - J. Lotman, Semiosfäärist. Tlk Kajar Pruul. Tallinn: Vagabund, lk 221-236.

M c Crone, David, M c Pher s o n, Gayle (toim) 2009. National Days: Constructing and Mobilising National Identity. Basingstoke: Palgrave Macmillan.

M o or a, Harri 1923. Eesti praegusest rahvuslusest. - Mõtteid valmivast intelligentsist. Tartu: Odamees / Carl Sarap, lk 61-67.

Mägi s t e, Julius 1937. Rahvuslike teaduste edust Eestis [1. osa]. - Looming, nr 3, lk 358-361.

Mägi s te, Julius 1973. Eesti rahvuslikest teadustest paguluses. - Eesti Keele ja Kirjanduse Instituudi aastaraamat I. Stockholm, lk 235-253. 
Ney, Gottlieb 1934. Eesti teadus ja teaduslik töö Eestis. - Eesti vaimse kultuuri saavutusi: Eesti Vaimse Kultuuri Päevade puhul 23. II - 25. II 1934. a. Tallinn: Eesti Vaimse Kultuuri Päevade Peakomitee kirjastus, lk 7-26.

Nu ut, J[üri] 1946. Progressiivse teaduse ülesandeid Nõukogude Eestis. - Eesti Bolševik, nr 6, lk 408-415.

Puschner, Uwe 2017. Verwissenschaftlichung der Weltanschauung. Völkische Aspirationen, Strategien und Rezeptionen in der langen Jahrhundertwende. - Handbuch der völkischen Wissenschaften: Akteure, Netzwerke, Forschungsprogramme. Toim Michael Fahlbusch, Ingo Haar, Alexander Pinwinkler. 2. tr. Berlin: De Gruyter, lk 9-18.

Rahvusvahelised rahvusteadused 2014. Artiklikogumik rahvusülikooli 95. juubeliks. Tartu: Tartu Ülikooli Kirjastus.

Rigney, Ann 2001. Imperfect Histories: The Elusive Past and the Legacy of Romantic Historicism. Ithaca, New York: Cornell University Press.

[Ränk, Gustav] 1943. Saavutusi eesti rahvusteaduste uurimistöös iseseisvuse ajal. Prof. dr. Ränga kõne vabaduspäeva aktusel Tartu Ülikooli aulas. - Postimees 25. II.

S mith, Anthony D. 2005. The genealogy of nations: An ethno-symbolic approach. - When is the Nation? Toim Atsuko Ichijo, Gordana Uzelac. London-New York: Routledge, lk 94-112.

Smith, Anthony D. 2013. The Nation Made Real. Art and National Identity in Western Europe, 1600-1850. Oxford: Oxford University Press.

S u tr o p, Urmas 2012. Kuidas me mõistame rahvusteadust? - Akadeemia, nr 7, lk $1155-1177$.

T a m m, Marek 2005. Rahvuste loomisest ja uurimisest. Vestlus Miroslav Hrochi ja György Schöpfliniga. - Sirp 26. VIII.

Tamm, Marek 2008. History as cultural memory. Mnemohistory and the construction of Estonian nation. - Journal of Baltic Studies, kd 39, nr 4, lk 499-516.

Tamm, Marek 2012. Monumentaalne ajalugu. Esseid Eesti ajalookultuurist. Loomingu Raamatukogu, nr 28-30. Tallinn: SA Kultuurileht.

T a m m, Marek 2013. Juri Lotman ja kultuurimälu teooria. - Akadeemia, nr 10, lk 1747-1770.

Tamm, Marek 2017. Euroopa rahvuslik ajalookirjutus võrdlevas vaatluses. Tuna, nr 2, lk 128-138.

To r o p, Peeter 2011. Tõlge ja kultuur. Tartu-Tallinn: Tartu Ülikooli Kirjastus.

Özkırımlı, Umut 2005. Contemporary Debates on Nationalism. Basingstoke: Palgrave Macmillan.

Özkırımlı, Umut 2010. Theories of Nationalism. A Critical Introduction. Second Edition. Basingstoke: Palgrave Macmillan.

Weindling, Paul 2017. Volk und Forschung: eine Wissenschaft für die Nation. - Handbuch der völkischen Wissenschaften: Akteure, Netzwerke, Forschungsprogramme. Toim Michael Fahlbusch, Ingo Haar, Alexander Pinwinkler. 2. tr. Berlin: De Gruyter, lk 1-8.

Wertsch, James V. 2002. Voices of Collective Remembering. Cambridge: Cambridge University Press.

Wimmer, Andreas, Glick Schiller, Nina 2002. Methodological nationalism and beyond: Nation-state building, migration and the social sciences. - Global Networks, kd 2, nr 4, lk 301-334. 


\section{Making the nations: A humanities point of view}

Keywords: nations, nationalism, national disciplines, humanities

This essay aims to offer a framework for discussing relations between nationalism and humanities. Nation-creation is a constant process, even if its intensity can vary over time. In this essay, four aspects of the process of nation creation from humanities perspective are examined: how nations are made through narration, performance, visualization and research.

Inspiring stories help create nations and keep them together. A nation is intrinsically a narrative community, whose identity is largely based on "stories to live by". Narrative patterns allow a nation to see itself as continuous, and agglutinate separate events into a meaningful whole instead of seeing them as a chain of coincidences.

All sorts of collective practices also play an important role - we could call these practices performing the nation. The backbone of the performance of nation is the calendar of national holidays, which lets people regularly recall and commemorate the past events considered the most important for the national identity.

Besides texts and performances, a third aspect is the major role of symbols in the process of nation-making. Particularly significant are the visual representations of the nations. The role of visual artists is to translate the abstract idea of nation into an accessible, emotionally laden symbolic language.

Finally, nations are made also through research, especially by the so-called national disciplines (rahvusteadused). The concept was introduced in Estonian around 1920s and taken probably from German or from Finnish. The cultivation of national disciplines, including the study of Estonian language, literature, history, folklore, archaeology, was considered highly important in 1930s, but the term was made popular also in post-war years during the early period of Soviet annexation. After falling into quasi-oblivion in late Soviet period, the concept of national disciplines made a surprising return in early 2000s, at the initiative of the Estonian Ministry of Education and Research.

Marek Tamm (b. 1973), PhD, Tallinn University, School of Humanities, Professor of Cultural History, marek.tamm@tlu.ee 